\title{
Adaptations to Climate Variability and Agrarian Crisis in Kolar District, Karnataka, India
}

\author{
B.N. Krishnakanth and B.C. Nagaraja $\dagger$ \\ Department of Environmental Science, Bangalore University, Bangalore-560 056, Karnataka, India \\ $\dagger$ Corresponding author: B.C. Nagaraja; nagenvi@gmail.com
}

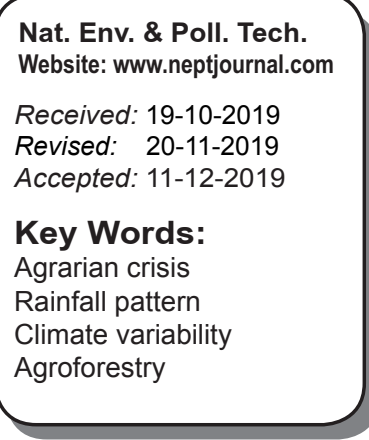

Nat. Env. \& Poll. Tech. Website: www.neptjournal.com

Revised: 20-11-2019

ed: $11-12-2019$

Agrarian crisis

Rainfall pattern

Agroforestry

\begin{abstract}
The dynamics in climatic variability is prominently affecting the agriculture system, particularly the small and marginal land holding farmers in arid and semi-arid regions which are highly vulnerable. The present study in Kolar district assessed the variability scale and dynamics of rainfall over the decades, it revealed the current day's agrarian crisis, resulting in impacts on farmers and adaptations by farmers to changing situations. The study also reveals that over the decades there has been a considerable variation in rainfall pattern in the study area but there was no significant average rainfall variation till the last decade, after which there was a significant seasonal variation that directly affects the sowing pattern and associated agricultural practices. The exploitation of groundwater for waterintensive commercial crops has increased rapidly from the past decade that resulted in the critically depleted groundwater table. To meet the livelihood demands some farmers were observed to have shifted to non-agricultural occupations. It is a serious threat at this point of time as the agriculture output has to be fed to the larger portion of the society and decreased output from agriculture eventually leads to inflation. So, it is very crucial to adapt all possible measures to retain farmers in agriculture practice. Hence, understanding and scientific assessment of the risks associated with the changing climate and its variables is the need of the hour, particularly in arid and semi-arid regions which are going to be highly vulnerable. Studies like this will help in policy-making and management planning to cope up with the dynamic climatic factors.
\end{abstract}

\section{INTRODUCTION}

Climate change is one of the most harmful global problems and considered a bottle-neck for sustainable development (Lema \& Majule 2009). Climate is an important factor for agricultural productivity and any variation in these factors is bound to result in a larger impact on crop yield (Ashalatha et al. 2012). Climate variability has proved and continues to be the prime cause of imbalance in global food production in the developing world, particularly in arid and semi-arid tropical countries. Agricultural productivity in tropical Asia is dependent not only on temperature variations but also to varying monsoon patterns (Sivakumar et al. 2005).

Agriculture in India accounts for a major share in GDP (16\%) and even shares major portion (49\%) of employment and also has the potential to act as a hindrance to development (Hari et al. 2018). In Karnataka, more than $70 \%$ of the geographical area is classified as an arid or semi-arid region which constitutes about $18 \%$ of land under this category in India (Nautiyal et al. 2018).

About 700 million (60\%) people in India are dependent on agriculture and associated occupations in one or the other way (Kuruvilla 2013). Failing to adapt to climate change by the farmers will result in the reduction of agricultural production by $12 \%$ average and by up to $18 \%$ in rain-fed areas by the end of this century (Hari et al. 2018). The current study was thus aimed at understanding the historical rainfall behaviour and the farmers' perception of climate variability, impacts and adaptation strategies in the agricultural sector in Kolar district.

\section{STUDY AREA AND METHODOLOGY}

Kolar is an administrative district in the South Indian state of Karnataka (Fig. 1). It is the headquarter of Kolar District and is historically known for gold mining. Administratively, the district is divided into 6 taluks, viz. Bangarpet, Kolar, Mulbagal, Malur, KGF \& Srinivasapur, 27 Hoblies and 156 Gram Panchayats. Among the taluks in the district, Srinivasapura is the biggest ( 860 sq. $\mathrm{km}$ ) and Malur is the smallest taluk (645sq.km). Kolar is also called the land of silk, milk and gold. Farmers are known for horticulture, floriculture, sericulture and growing vegetable crops. The district lies almost in the central part of peninsular India, which has an immense bearing on its geo-climatic conditions. The district 


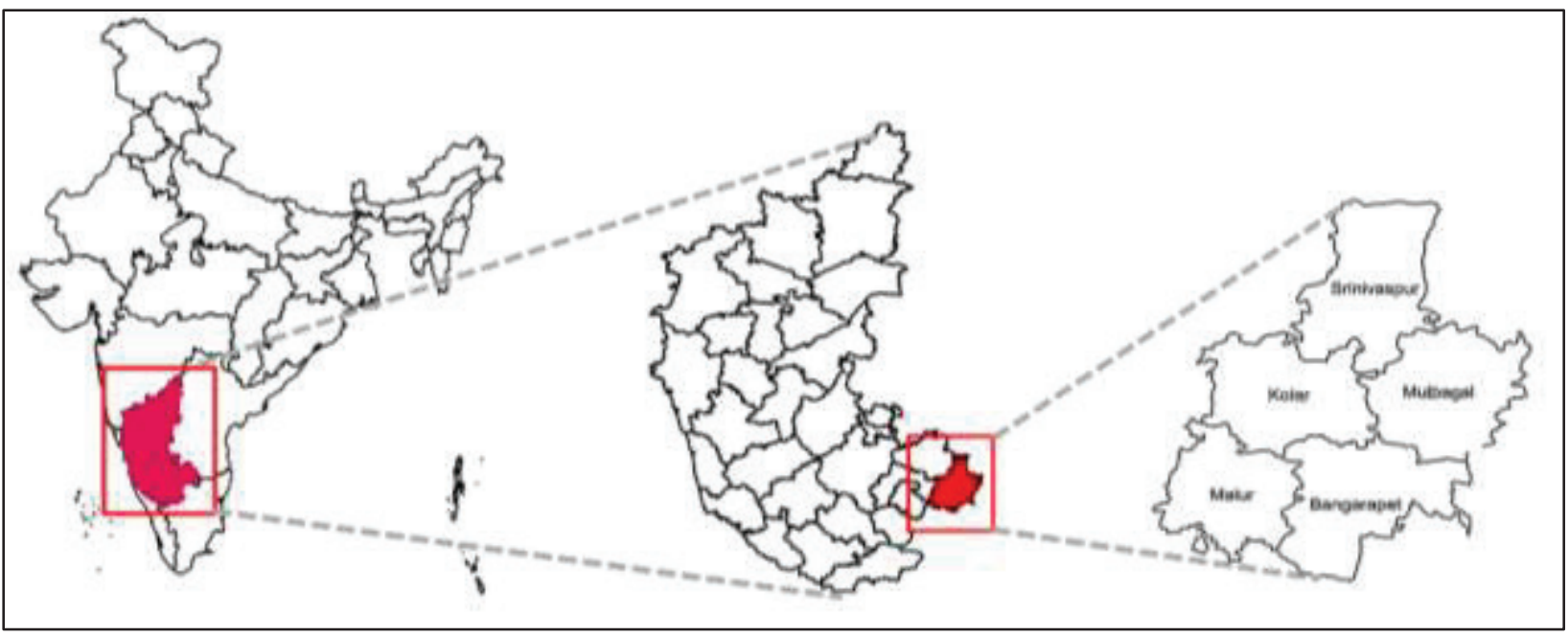

Fig. 1: The study area.

has about 29936 bore wells which are also highest in the state and is the main source of irrigation.

The primary objective of this study was aimed at understanding the farmers' perception of climate and variability, impacts and adaptation strategies in the agricultural sector. Both secondary and primary data were used. A mixed-method approach (combination of quantitative and qualitative methods), along with tools from both social and environmental sciences were used for primary data collection. Tools such as Participatory Rural Appraisal (PRA) and Focus Group Discussions (FGD) (Uddin \& Anjuman 2013) were adopted to understand the historical agriculture in the region. A total of 61 households in villages from Bangarpet, KGF, Kolar, Malur, Mulbagal and Srinivaspura taluks were interviewed. The combined use of qualitative and quantitative techniques, particularly in assessing the adaption and impacts in agriculture can give us the confidence about what information is being gathered, observed, measured and analysed to arrive at the findings (Place et al. 2007).

\section{RESULTS AND DISCUSSION}

\section{Rainfall Trend Analysis}

Rainfall is an important climatic factor that plays a vital role in agriculture, particularly in the arid and semi-arid regions, where the availability of surface and groundwater is very less. Agriculture productivity is the key contributor to the country's economy and declined agriculture production due to altering climatic factors will result in various socio-economic crisis.

To understand the historical behaviour of rainfall, day-wise rainfall data of the study area was acquired from
Karnataka State Natural Disaster Management Centre from 1971 to 2017 and analysed. The five decadal rainfall trend analysis (Fig. 2) revealed that Mulbagal taluk received consistent rainfall compared to other taluks of the study area with a mean rainfall of $812 \mathrm{~mm}$. During 1981-1985, it received the lowest average rainfall of $630 \mathrm{~mm}$ and the highest annual average rainfall of $924 \mathrm{~mm}$ was recorded during 1996-2000. Kolar taluk stands second with a mean rainfall of $807 \mathrm{~mm}$, highest annual average of $926 \mathrm{~mm}$ during 1996-2000 and lowest of $632 \mathrm{~mm}$ during 1981-1985. Malur, Bangarpet and Srinivaspur taluks showed that there is a moderate amount of variation in rainfall over the decades. The mean rainfall during the last 4.5 decades among the 5 taluks ranged from 770-812 mm, which reveals that Kolar district historically received consistent annual rainfall without any considerable variation in rainfall.

The monthly average rainfall data of the last decade were analysed to understand climate variability in Kolar district (Fig. 3 ). The results revealed that December, January, February and March received a negligible amount of rainfall except March received $75 \mathrm{~mm}$ in 2008 and December received $81 \mathrm{~mm}$ in 2016, April received mean rainfall of $45 \mathrm{~mm}$ with the highest monthly average of $105 \mathrm{~mm}$ during 2015 and lowest of $3 \mathrm{~mm}$ in 2016. Whereas May received more rainfall compared to June and July months with a mean rainfall of $109 \mathrm{~mm}$, highest of $163 \mathrm{~mm}$ and lowest of $70 \mathrm{~mm}$. May has behaved more consistently in rainfall throughout the decade. June and July months which are beginning of monsoon in Karnataka exhibits similar behaviour in the entire decade with the lowest rainfall of $23 \mathrm{~mm}$ in 2008 and highest of $176 \mathrm{~mm}$ in 2016. June, July and August months showed a considerable amount of variation in rainfall throughout the decade, it indicates that it influences 


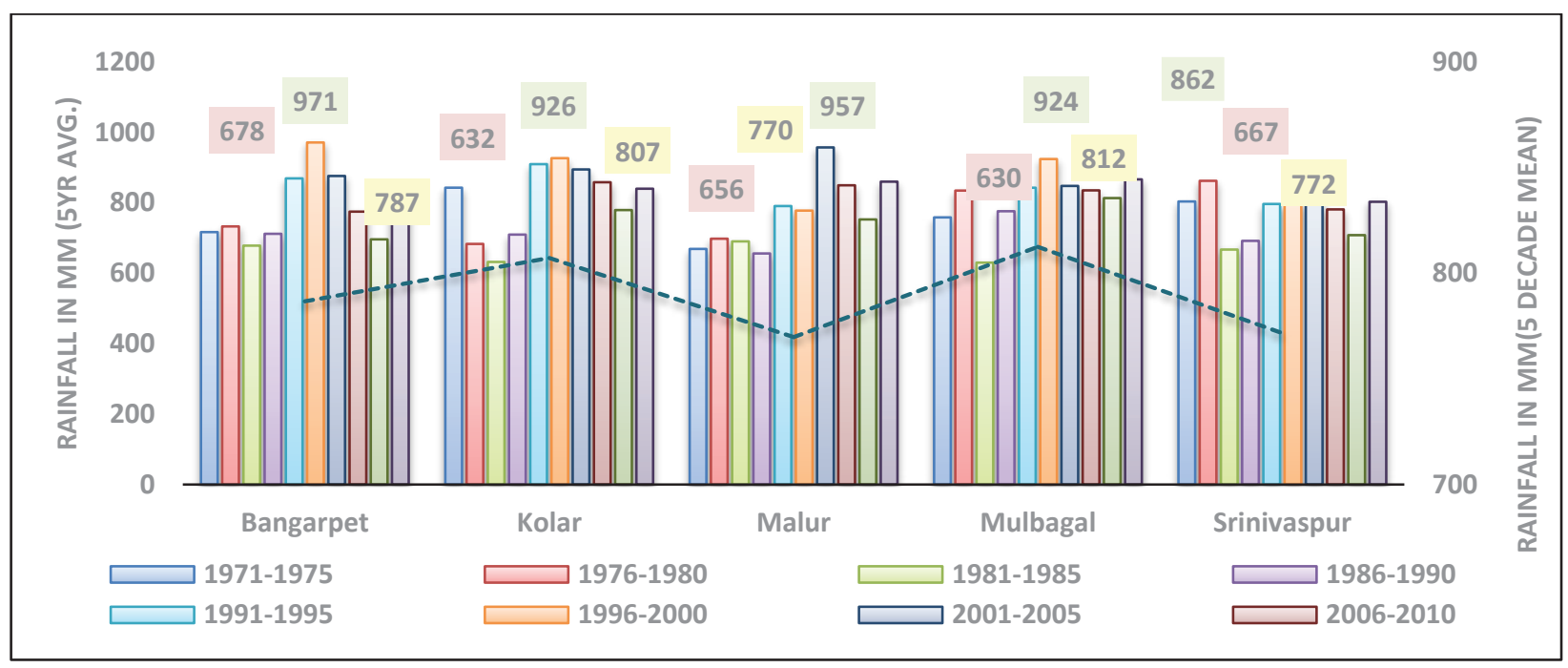

Fig. 2: Five-year average rainfall trend in the last four and half decades of Kolar District.

rain-fed cropping in the region. September which falls in the latter part of monsoon received maximum rainfall in a year for the entire decade with a mean rainfall of $131 \mathrm{~mm}$, highest of $268 \mathrm{~mm}$ in 2009 and lowest of $31 \mathrm{~mm}$ in 2012. October and November fall in post-monsoon season, of which October received maximum rainfall with a mean rainfall of $122 \mathrm{~mm}$ and highest of $310 \mathrm{~mm}$ during 2017, but November 2015 recorded highest average rainfall of $349 \mathrm{~mm}$.
To understand the inter-seasonal variation in rainfall, season-wise average rainfall analysis (Fig. 4) was conducted for last one decade, March and May months were categorized as pre-monsoon, June to September as monsoon and October to December as post-monsoon seasons. The results revealed that pre-monsoon received a mean rainfall of $173 \mathrm{~mm}$, the highest rainfall of $228 \mathrm{~mm}$ in 2015 and lowest of $121 \mathrm{~mm}$ during 2014. Result also revealed that average pre-monsoon

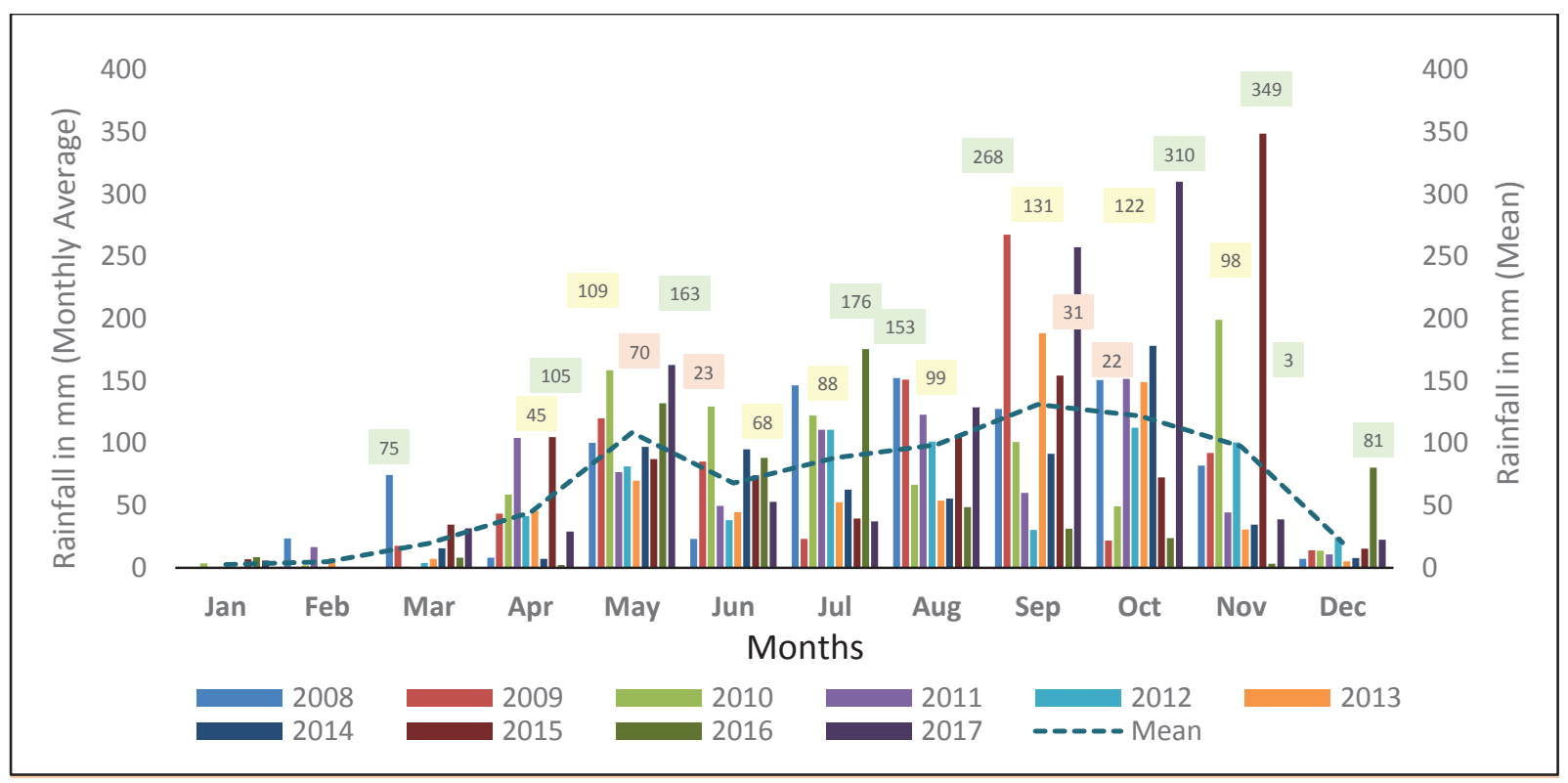

Fig. 3: Decadal monthly average rainfall trends in Kolar district. 


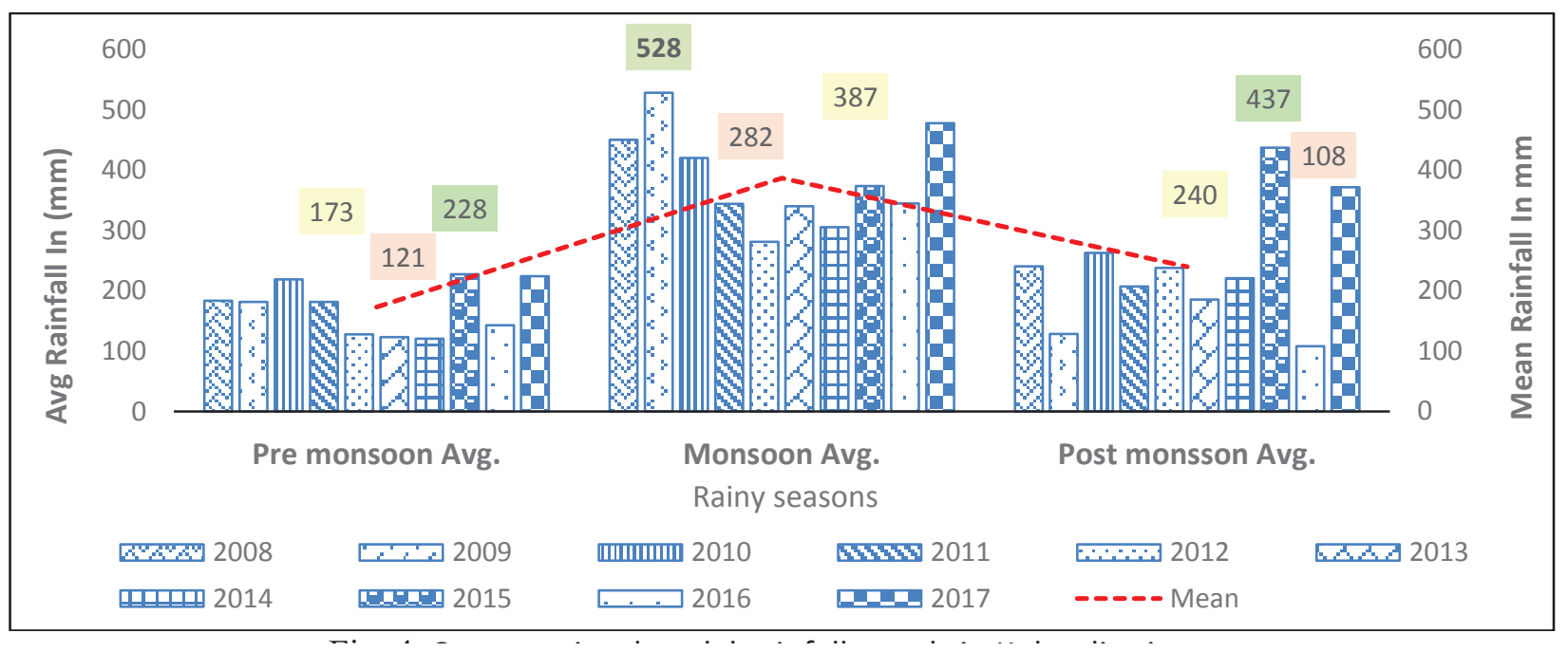

Fig. 4: Season-wise decadal rainfall trends in Kolar district.

rainfall showed downtrend from 2010 to 2014. Monsoon season received mean rainfall of $387 \mathrm{~mm}$, highest of 528 $\mathrm{mm}$ in 2009 and showed downtrend till 2012, lowest was 282 $\mathrm{mm}$ in 2012 and from 2013 the rainfall showed an increasing trend. Post monsoon has irregularly behaved throughout the decade with the highest rainfall of $437 \mathrm{~mm}$ in 2015 to lowest of $108 \mathrm{~mm}$ in 2016 with a mean rainfall of $240 \mathrm{~mm}$.

\section{Agrarian Crisis}

The information on farmer's perception, climate variability and adaptations to the agrarian crisis was collected from selected households in villages falling in the study area. Study reveals that all the respondents opined that they are experiencing irregular monsoon in the last one decade.

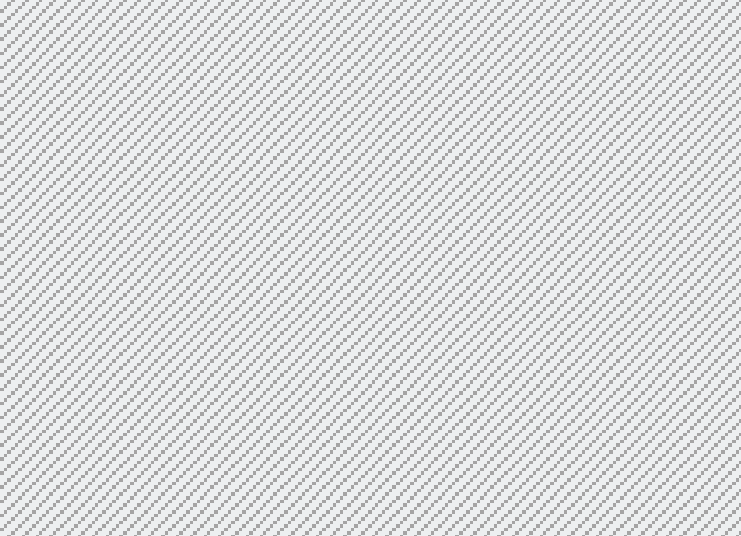

Fig. 5: Farmer's perception on Drought.
About $72 \%$ of respondents opined that irregular monsoon attributes for drought scenario, $12 \%$ respondents expressed groundwater depletion while $9 \%$ expressed dependency on water-intensive crops, and $6 \%$ opined unscientific agriculture practices and $1 \%$ respondents expressed that all the above factors attribute for drought (Fig. 5). About $42 \%$ of the respondents opined overexploitation of groundwater, $36 \%$ opined lack of rainfall, $14 \%$ opined eucalyptus plantation while $8 \%$ expressed lack of rainwater harvesting measures as the reasons for bore-well failure in the region (Fig. 6). Regarding fallow land, 70\% opined water shortage as the prime cause, while $25 \& 20 \%$ respondents expressed lack of capital and labour shortage respectively as the reasons accounting for fallow land (Fig. 7).

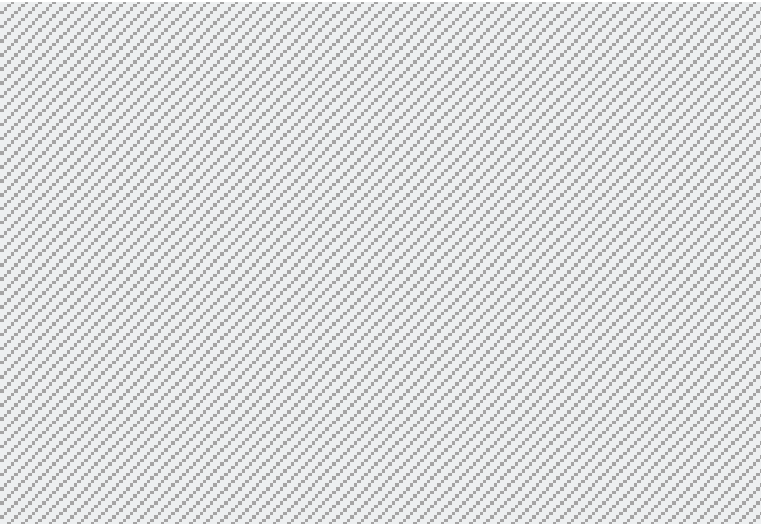

Fig. 6: Farmer's perception on bore-well failure.। 


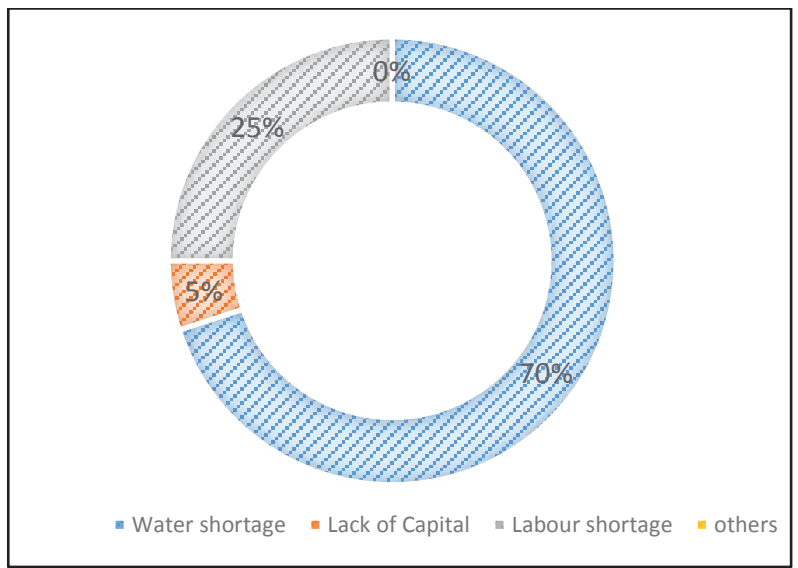

Fig. 7: Farmer's perception on fallow land.

Table 1: The tree population in Kolar district, Karnataka.

\begin{tabular}{|c|c|c|}
\hline Sl. No. & Tree Species & No. of individuals \\
\hline 1 & Santalum album $\mathrm{L}$. & 850 \\
\hline 2 & Mangifera indica $\mathrm{L}$. & 709 \\
\hline 3 & Tectona grandis L. f. & 366 \\
\hline 4 & Eucalyptus globulus Labill. & 341 \\
\hline 5 & Pongamia pinnata (L.) Pierre & 224 \\
\hline 6 & Azadirachta indica A. Juss. & 217 \\
\hline 7 & Tamarindus indica $\mathrm{L}$. & 191 \\
\hline 8 & Melia dubia Cav & 160 \\
\hline 9 & Grevillea robusta A. Cunn. ex R. Br. & 150 \\
\hline 10 & Anacardium occidentale L. & 150 \\
\hline 11 & Syzygium cumini var. cumini & 19 \\
\hline 12 & Moringa oleifera Lam. & 4 \\
\hline 13 & Cinnamomum camphora (L.) J. Presl & 4 \\
\hline 14 & Aegle marmelos (L.) Correa & 3 \\
\hline 15 & Artocarpus heterophyllus Lam. & 1 \\
\hline 16 & Ficus benghalensis L. var. krishnae (C. DC.) Corner & 1 \\
\hline 17 & Murraya koenigii (L.) Spreng. & 1 \\
\hline \multirow[t]{2}{*}{18} & Manilkara zapota (L.) P.Royen & 1 \\
\hline & Total & 3392 \\
\hline 1 & Cocos nucifera $\mathrm{L}$. & 719 \\
\hline 2 & Musa paradisiaca $\mathrm{L}$. & 30 \\
\hline \multirow[t]{2}{*}{3} & Carica papaya $\mathrm{L}$. & 17 \\
\hline & Grand Total & 4158 \\
\hline
\end{tabular}




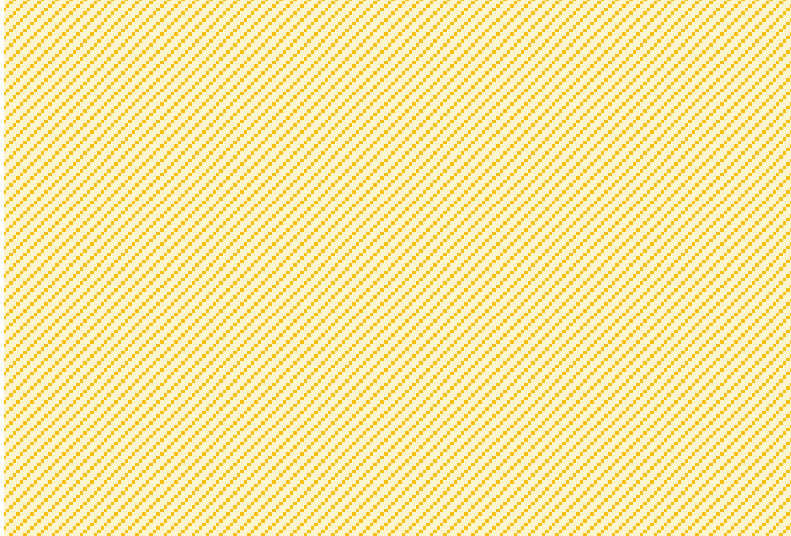

Fig. 8: Agricultural best practices.

\section{Adaptations}

Agroforestry practice is essentially important to overcome the impacts of prolonged droughts and crop failure resulting from monsoon shifts. Farmers can rely on agroforestry as an alternate source of income during drought, it also plays a vital role in integrated soil nutrient management, providing a sustainable source of fodder and timber. Results of the household survey revealed that $85 \%$ of the respondents practiced agroforestry that includes 18 tree species, predominantly Santalum album and Mangifera indica (Table 1).

The present study revealed that $72 \%$ farmers practiced micro-irrigation system and $18 \%$ used mulching techniques, $2 \%$ adopted night-time irrigation, $5 \%$ used shade crops to avoid evaporation after irrigation and 3\% practiced rainwater harvesting (Fig. 8). Further, 88\% farmers incorporated drip irrigation, $6 \%$ used sprinkler system, $2 \%$ practiced zero tillage method to preserve soil moisture and $4 \%$ shifted to drought resistant crop varieties to cope with water scarcity (Fig. 9).

Survey also revealed that some farmers have shifted to other occupations to feed the livelihood demands, $15 \%$ farmers have shifted to other occupations to overcome drought impacts, about $23 \%$ respondents expressed low yield in agriculture as the reason for the shift, 23\% opined low rainfall, $23 \%$ expressed non-availability of the marketplace, $14 \%$ opined labour shortage, $4 \%$ expressed middle man interference while $9 \%$ opined as other reasons.

About $48 \%$ of farmers expressed that there is support from the Government to mitigate Agrarian crisis with adequate financial resources and $52 \%$ expressed that there is no support. Programs such as farm pond, crop insurance and distribution of free seeds and fertilizers were found to be most effective as 34,35 and $28 \%$ farmers opined

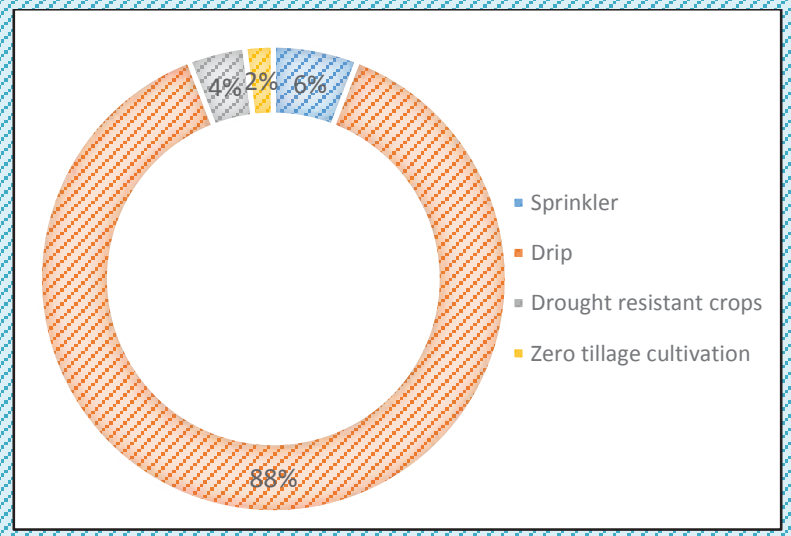

Fig. 9: Irrigation Measures to conserve water.

respectively, while only $3 \%$ expressed crop appreciation pay as benefiting.

\section{CONCLUSION}

Over decades there was a considerable variation in rainfall pattern in the study area, but there was no significant average rainfall variation till the last decade. This significant seasonal variation directly affects the sowing pattern and associated agricultural practices. Increase in the exploitation of groundwater for water-intensive commercial crops has increased rapidly from the past one decade resulting in the critically depleted groundwater table. Adding to this, there are no effective rainwater harvesting and recharge mechanisms in the region. Farmers are fighting repeated droughts and irregular monsoon, resulting in shifting of farmers from agriculture to other occupations which eventually leads to inflation. Hence, it is very crucial to adapt all the possible measures to retain the farmers in agriculture practice. Even though the government have taken up several programs, it was observed that there are still significant gaps in effective implementation and percolation of benefits to the end users. More importance should be given on precise farming practices, promoting sustainable agriculture and irrigation practices, soil nutrient management, watershed development, dairying and animal husbandry to improve the livelihood of the farmers.

\section{REFERENCES}

Ashalatha, K.V., Munisamy, G. and Bhat, A.R.S. 2012. Impact of climate change on rainfed agriculture in India: A case study of Dharwad. International Journal of Environmental Science and Development, 3(4): 368-371.

Hari, S. Khare, P. and Subramanian, A. 2018. Climate change and Indian agriculture. Article retrieved from https://voxdev.org/topic/agriculture/ climate-change-and-indian-agriculture. 
Kuruvilla, B. 2013. Report on the agrarian crisis in India and Climate Change. Roxa Luxemburg Stiftung, South Asia.

Lema, M.A. and Majule, A.E. 2009. Impacts of climate change, variability and adaptation strategies on agriculture in semi arid areas of Tanzania: The case of Manyoni District in Singida Region, Tanzania. African Journal of Environmental Science and Technology, 3(8): 206-218.

Nautiyal, S. Bhaskar, K. and Khan, I. Y. D. 2018. Biodiversity conservation in semi-arid landscape. Central and North Eastern dry zones of Karnataka. Policy brief-17. Institute for Social and Economic Change. Retrieved from http://www.isec.ac.in/Policy\%20Brief\%2017_Biodiversity_conservation_in_semi_arid_landscape_of_Karnataka_final.pdf

Place, F. Adato, M. and Hebinck, P. 2007. Understanding rural poverty and investment in agriculture: An assessment of integrated quantitative and qualitative research in Western Kenya. World Development, 35(2): 312-325.

Sivakumar, M.V.K. Das, H.P. and Brunini, O. 2005. Impacts of present and future climate variability and change on agriculture and forestry in the arid and semi-arid tropics. In increasing climate variability and change. Springer, Dordrecht., pp. 31-72

Uddin, M.N. and Anjuman, N. 2013. Participatory rural appraisal approaches: An overview and an exemplary application of focus group discussion in climate change adaptation and mitigation strategies. International Journal of Agricultural Research, Innovation and Technology, 3(2): 72-78. 